\title{
Dystopias in the Realm of Popular Culture: Introducing Elements of Posthuman and Postfeminist Discourse to the Mass Audience Female Readership in Cecelia Ahern's Roar (2018)
}

\section{ABSTRACT}

This article analyzes selected short stories in Cecelia Ahern's thirty-narrative collection Roar (2018) to see how (and with what losses or gains) the perspectives of posthuman and postfeminist critique can be incorporated via the common dystopic umbrella into the mainstream female readership of romance literature. The dystopic worlds created by Ahern in Roar portray inequality and power imbalances with regard to gender and sex. The protagonists are mostly middleaged women whose family and personal lives are either regulated by dystopic realities or acquire a "dystopic" dimension, the solutions to which are provided by, among other tropes, "posthuman" transformations. Roar introduces otherthan-human elements, mostly corporeal alterations, in which the female bodies of Ahern's characters become de-formed and re-formed beyond androcentric systems of value. The article raises the question of whether feminist and, to some extent, "posthuman" (speculative) approaches, need to be (and indeed should be) popularized in such an abridged way as Ahern does in her volume. The answer depends upon the identification of the target audience and their expectations. Ahern's Roar represents popular literature intended to be sold to as many readers as possible, regardless of their education, state of knowledge, etc. Viewed from that perspective, what some critics could perceive as the collection's structural weaknesses constitutes its utmost marketing asset. The essay argues that despite not being a structurally innovative work of art, Ahern's book fulfils the basic requirements of the popular fiction genre, intermittently providing some extra, literary gratification and popularizing rudimentary elements of the posthuman and postfeminist thought.

Keywords: popular culture, popular literature, romance novels, the feminist discourse, dystopia, the posthuman, Ahern. 
As a separate genre, popular fiction is claimed to be generated in regular intervals rather than "created" and mostly constitutes a mode of diversion, possessing a considerable degree of commercial capacity (Gelder 15, 35). In Popular Fiction: The Logics and Practises of a Literary Field, Gelder aptly points out that these specifics make critics consider the genre to be inferior and sub-standard in relation to high-brow Literature. Consequently, the above-cited scholar observes that nowadays it has become a

commonplace to regard popular fiction derisively as capitalism's most perfect literary form. It is as if popular fiction is "pure ideology," simply a matter of commerce, nothing more or less than a "product"-whereas Literature (so the argument goes) is more complicated, resisting ideological reduction, disavowing its commercial identity, able to criticize rather than capitulate to capitalism, enmeshed in nothing less than life itself. (Gelder 35)

Bearing Gelder's arguments in mind, one has to agree with him that it would be a crude simplification, and a form of cultural prejudice, to regard popular literature entirely as a marketing product which conveys the oneto-one ideological system of consumerist capitalism. Following this line of thinking, a key theorist of the popular culture, John Fiske, reminds us that

[p]opular culture is not consumption, it is culture-the active process of generating and circulating meanings and pleasures within a social system: culture, however industrialized, can never be adequately described in terms of the buying and selling of commodities. Culture is a living, active process: it can be developed only from within, it cannot be imposed from without or above. (23)

Recognizing culture in general, and popular culture in particular, as "a living, active process" provides a feasible argument why blurring the boundaries between the so-called high and low forms of culture should not be accompanied by reducing the latter solely to purely commercial practices regulated from above. These practices naturally constitute a vital component of the genre but they do not exclude other merits of such writing convention. The following article explores an attempt to bridge the differences between popular, and relatively accessible, writing for women and the more advanced postfeminist and posthuman thought.

Cecelia Ahern, daughter of Bertie (Bartholomew Patrick) Ahern (Taoiseach, Irish Prime Minister 1997-2008), a best-selling Irish author of the new generation (born in 1981), is considered to be an iconic writer of contemporary popular literature for women. She came to literature from a mass media background: she graduated from Journalism and 
Media Communications and even had a brief singing career in Ireland's finals qualifying for the 2000 Eurovision Song Contest ("Cecelia Ahern," Fantastic Fiction profile). Ahern fulfils all the aforementioned conditions of popular fiction: her books provide entertainment for readers, she has achieved global commercial success (the Hollywood adaptations of two of her novels have become international box office hits, while the rights to the collection analyzed in this article have been sold, as well), and she writes regularly, publishing, as assured on her website, one book a year. Furthermore, her website informs us that the author "sold 25 million copies internationally ... published in over 40 countries, in 30 languages." Ahern specializes in romance novels, record breaking in terms of sales, such as PS, I Love You (2004), Where Rainbows End (2004), Thanks for the Memories (2008), How to Fall in Love (2013), The Year I Met You (2014). The genre that has brought Ahern international fame, popular romantic fiction, in its pure and most classic form, can be distinguished by its sentimental subject matter, "plot predictability" (Killeen 55), submissive female protagonists, frequently resembling damsels in distress, "antiseptic and wan heroines needing rescue by older, wealthier men-a legacy of the Gothic romance ... more liable to faint than fight back" (Killeen 57), heroines not only saved but sexually awakened by active male protagonists, and by "happily ever after" resolutions of the narrative. Killeen indicates the generic term HEA ("Happily Ever After") as the condition sine qua non for this genre (55).

Traditionally, literature written for a mass audience tends to be conservative in content, and it rarely incorporates emancipatory, progressive or overtly controversial issues. There is an implicit assumption that "the romance's conservative ideology about the nature of womanhood is inadvertently 'learned' during the reading process and generalized as normal, natural, female development in the real world" (Radway 186). In this way, stereotypical notions, i.e. about women's allegedly innate passivity are upheld in the mass audience's consciousness. Killeen argues that second wave feminism reinforced the conviction that "romance is 'bad' (especially for women)" (56) since it implicitly reinstates patriarchal values. Considering the above, it comes as no surprise that the terms "popular romance genre" and "feminist" are not frequently used in one sentence in an affirmative context. However, as proved by Killeen, there are popular romance authors, such as Roberts (one can add Ahern to this group, as well) who attempt to redefine the boundaries of this genre and create independent-minded female protagonists in tune with the spirit of contemporary times. What is more, Radway recognizes an empowering potential for women in the fact that "romance reading originates in the very real dissatisfaction and embodies a valid, if limited, protest" (220). 
Consequently, she envisages a further feminist development by employing the "strategies for making that dissatisfaction and its causes consciously available to romance readers and by learning how to encourage that protest in such a way that it will be delivered in the arena of actual social relations rather than acted out in the imagination" (220). Furthermore, to achieve these aims, Radway draws attention to the need to acknowledge "the complexity of mass culture's implication in social life" (220-21). With regard to her claim, postfeminism seems to be positively predisposed towards exploring these intricacies. As Tasker and Negra emphasize, postfeminism is deeply rooted in popular culture; it is receptive to popular trends and commercial preferences, and, what is more, it "elevates consumption as a strategy for healing those dissatisfactions that might alternatively be understood in terms of social ills and discontents" (2). Tasker and Negra argue that it focuses on women's choices, opportunities and possibilities rather than constraints and obstacles (2-3). The Chick Lit genre (the fusion of popular romance fiction and postfeminist culture), which emerged at the turn of the twentieth century, is defined as a "female oriented form of fiction and a highly successful commercial literary phenomenon" (Genz and Brabon 84). The female protagonists of such novels are allegedly "liberated" from patriarchal restraints, and viewed as acting from a place of female agency as they pursue their autonomous goals. Nonetheless, it seems that this new writing convention nearly routinely departs from former, feminist-oriented goals. ${ }^{1}$ Consumer (post)feminism has different objectives: its addressee is supposed to make good use of the earlier gains of the women's movement, while at the same time, distancing herself from the feminist ethos. ${ }^{2}$

With her young age and world-wide marketable success, Ahern is not a pioneer of the women's movement but she evidently draws benefits (including financial ones) from the social and cultural advances made by the second generation activists. Likewise $21^{\text {st }}$-century Ireland is no longer the same place it was in the previous millennium. The secular turn, multicultural policy, post-Celtic Tiger trauma and changes in gender equality legislation have had an impact upon the country's development. Ahern, as a proverbial thirty-something, enterprising icon of popular (postfeminist) writing, advocates that, even though, regardless of the radical changes in

Helen Fielding's canonical Bridget Jones book series boasts a protagonist (especially in the early volumes) who speaks lightly of sexual harassment in the workplace and has a limited awareness of global culture, politics or feminist agenda. McRobbie emphasizes Jones's dream of the married life as being a central part of her future plans (36-38).

2 The question of distinguishing the second wave from the third one is explored in detail in my article "From the Kitchen into the Bathroom: Feminist (post) Theory in Crisis.” 
Irish society that happened over the last decades, there still exist crucial female struggles and feminist objectives that are not accomplished and that are worth fighting for. Roar seems to underscore that it takes more time and effort to alter people's mentality and cultural habits than to eradicate discriminatory laws and regulations. As argued here, Ahern strives (not without stylistic deficiencies and structural shortcomings in the text) to make an astonishing progression from popular fiction into what Angela McRobbie ironically defines as "unpopular feminism" (31-34) and even less popular posthuman stylistics. Roar (2018) seeks to usher the devoted, mass reading public of Ahern's earlier romance novels into the world of more challenging dilemmas with some elements of the dystopian reality and posthuman critique; not without failures, it must be admitted.

Presenting "thirty stories/thirty women," Roar examines contemporary problems related to cultural femininity and the strict gender policing perceived as women's confinement ("The Woman Who Wore Pink," "The Woman Who Was Pigeonholed," "The Woman Who Was a Featherbrain," "The Woman Who Lost Her Common Sense," "The Woman Who Was Kept on the Shelf," "The Woman Who Found Bite Marks on Her Skin," "The Woman Who Walked in Her Husband's Shoes"). Some narratives explore women's self-definitions in the context of their social visibility and representation ("The Woman Who Slowly Disappeared," "The Woman Who Had a Ticking Clock" and "The Woman Who Thought Her Mirror Was Broken"). Others are organized around metaphors of much desired freedom and defiance: "The Woman Who Grew Wings" or "The Woman Who Found the World in Her Oyster," "The Woman Who Smiled," "The Woman Who Had a Strong Suit," "The Woman Who Returned and Exchanged Her Husband." Different as they might be, all the stories explore the (negative) gender stereotypes held by society (and sometimes internalized by the protagonists themselves), and seek ways out of the impasse. The following article is going to focus only on two tropes of these critical practices: dystopian and posthumanist ones. To make it clear, the term posthumanist is used in the article as a mode of beyond human female bodily transformations, in which the materialities of female bodies, their domestic surroundings, milieu and the androcentric worldview become re-constituted; evidently, in Ahern's fiction, the philosophical claims of posthumanism feature in a much diluted and mass audiencefriendly version.

In the dystopian reality of "The Woman Who Spoke Woman" located in the not so distant past (future?), there is only one recognized language: a "man-speaking" dialect. The short story, which constitutes a shrewd political satire on mansplaining, depicts a men-only government, in some unspecified, patriarchal country run by a male Prime Minister (and 
resembling Ireland before Mary Robinson's presidency) who declare their apprehension about losing the support of female voters. Oblivious to women's specific needs or interests, the male politicians are deeply convinced that they represent the whole population of the country: "But we speak for everyone,' one says. 'We act on all of our citizens' behalf'” (Ahern 246). Relating to female voters, statesmen refuse to concede that men in power "don't act on their behalf. And . . . don't listen to their concerns" (246, emphasis in the original). In the cabinet's view, men's problems are identified as universal and referring to all "mankind," whereas "women's issues" generate nothing more than an unnecessary obstruction in the government's management. When an accomplished and attractive female protagonist is invited to give a speech in front of the all-male governing body, the politicians do not understand her parlance. They need to be informed in an interpretive manner that the orator "was speaking our national language but she was speaking the woman's version" (248). In "The Woman Who Spoke Woman," the fact that female characters might have their own idiom is both incomprehensible and threatening to men's authority. Referring to the Prime Minister, the advisor clarifies that the "women of this country wish you to understand their dialect, and they also wish women who speak this dialect to join the government" (248). In Ahern's short story, female politicians are not generically regarded as the representatives of "all the country's citizens" (249, emphasis in the original), since they are solely allowed to stand for the questions regarding their own gender. In the world of governmental affairs, men are willing to listen to women but only to those who can express themselves in the "dewomanized ... male dialect" (251). In "The Woman Who Spoke Woman," the Prime Minister elucidates the generally-binding responsibilities of statesmen: "the men are just the men-their role is to be a man, no distractions. When they speak, they speak man, and everybody hears them" (254). In contrast, women's administrative utterances might only be acknowledged as providing a tactical diversion from the inconvenient matters that the government may wish to bury. The advisor (who in Ahern's short story is subversively a woman disguised as a man) sums up the proceedings: "we need man-speaking-women in the government to discuss everyday issues, man-speaking-women to translate the women's issues, and we need women-women to distract from the more troubling male issues" (254). As demonstrated in "The Woman Who Spoke Woman," women's statements can be taken into consideration as long as they are articulated in men's language, and when they are consistent with men's interests rather than women's own objectives.

The dystopian "The Woman Who Wore Pink" captures the absurdities of an anatomical categorization of socio-cultural roles and gender 
identifications. In some near future, alternate reality, sole two legitimized gender taxonomies are assigned at birth on the basis of one's biological sex and no individual can deviate from the legally enforced Gender Discipline. Ironically, open to redefinitions and renegotiations, gender as a category was introduced precisely to avoid biological reductionism. However, in Ahern's short story, sex-based binary classifications replace one's preferred gender identifications, and to stress this fact everybody is lawfully termed as either "penis" (instead of man) or "vagina," signifying woman (or rather an assumption that every woman needs to be cisgender). The linguistic designation system works like a synecdoche in which a (body) part stands for the whole (person): one biological organ is meant to represent one's entire subjectivity. In the dual sex-categories regime, penises are obligatorily marked by blue bands on their wrists and blue objects they possess, while vaginas have to wear pink bracelets, use only pink taxis and behave in the way that is officially recognized as compliant with their gender. The Gender Recognition Act of 2017 regulates all the norms of social conduct and verbal expression with regard to women's and men's expected behaviour. If a vagina should violate these rules, she can get penalty points, a fine or a court sentence. Generally, women are not allowed to openly refuse men's help, regardless of whether they need it or not. They also cannot offer assistance to men; Mary Agronski (a "naughty vagina"), who held the door open for a man, is punished by the Gender Police and re-educated that " $[\mathrm{p}]$ olite would mean you allowing that man to be helpful to you. Polite means everyone knowing their place and making sure we don't upset the foundations of our society" (Ahern 209). Another female culprit is disciplined for declining a man's offer to assist her with carrying the shopping. Her assertive refusal is penalized as an act of belligerence. Any declaration such as "This vagina is well able to take out the rubbish" is viewed as an insubordinate transgression (221). As seen, all forms of verbal or behavioural disobedience questioning the Gender Recognition Act, are castigated by the Gender Police: "The female gender cop is dressed in a candy-pink uniform and her younger male partner is dressed in baby blue. The two saccharine colours pop in an otherwise muted world" (208).

Moreover, Ahern's “The Woman Who Wore Pink" raises the vital issue of transgender people who defy binary sexual divisions. In a different short story from the same volume, "The Woman Who Found the World in Her Oyster," oysters, as stressed by the narrator, signify transsexual creatures: they begin their life cycle as males which discharge sperm, and later, they turn into females and produce eggs. This inclusive metaphor of the fluid and non-binary sexuality of the natural world reaffirms the transgender protagonist of the aforementioned narrative and comforts 
her. "The Woman Who Wore Pink" draws attention to the limitations of the twofold gender model and to the dangers it poses for the transgender community. When the official colour band on one's wrist clashes with one's preferred gender identification, it might put people's lives in jeopardy from violent transphobes or lead to undesired disclosure in a professional context. Unfortunately, vital as the problem is, the short story seems to avoid ambiguities at any cost; the narrative is slowed down by the detailed summary of ongoing events and frequent repetitions: "he's embarrassed, and feels degraded. She catches his eye and does her best to offer him a supportive smile but the damage has been done already. . . . It seems such a simple thing, pink and blue gender recognition, but such simple acts as these mean so much more than she thought" (Ahern 211). The above citation reveals the exact problem with Ahern's fiction: her earlier emblematic romance mode seems to compete for primacy with the profound subject matter of the writer's recent prose. To a large extent, clarifying passages, like the ones related above, constitute an essential element of the popular fiction pact between writers and readers. This is how Radway explains such a mutual understanding:

Romances further obviate the need for self-conscious interpretation by almost never assuming that their readers are capable of inferring meaning, drawing conclusions, or supplying "frames." Typically, after describing a verbal response that any reader can infer is prompted by anger, the writer confides redundantly, "she was angry." Repetition is the rule, not the exception governing these novels. Even in passages obviously intended to evoke a mood, romance writers cannot resist the temptation to assist the reader in her interpretative efforts. (196)

It seems that Ahern has transposed the popular genre convention into her more ambitious current writing quite uncritically. Let us consider a blameless, derisive passage, mocking Starbucks's direct marketing manner of calling customers by their first names, offered by the company together with hundreds of coffee options. In the new reality, there are only two binary oppositional "personal" identification tags- "a chorus of 'penis,' 'vagina,' 'vagina,' 'penis'” (Ahern 206) which—when juxtaposed with copious, sophisticated product selections, creates an ironically amusing effect. The world can recognize thousands of variants of coffee brands but only two types of customers: "Cappuccino, no chocolate, penis! . . . Grande latte to go, please. Vagina” (206). If Ahern had decided to leave this well-played scene as it is, it could have stayed long in readers' minds. But instead, the writer needs to cross the "Ts" and dot the "Is" and provide a ready-made interpretation for readers in the way in which the order is 
placed: "One latte for a human being" (Ahern 223). As argued earlier, such structural flaws and supplementary stylistic habits are the trademarks of the "romantic writing" in which Ahern specializes. Radway sums it up pertinently:

$[R]$ edundancy and overzealous assertion ... combat ambiguity, imply that all events are definitely comprehensible.... these techniques cancel the anxiety and contingency prompted by the fact that reading is a temporally open-ended act. ... By masking the interpretative character of the act of reading, the redundant and simple language ... minimizes the labor that the reader contributes to the production of the story. (196)

Two other dystopian short stories, "The Woman Who Guarded Gonads" and "The Woman Who Returned and Exchanged Her Husband," reverse the gender power dynamic and imbalance, only this time men's wor(l) ds are controlled by women and not vice versa. The first narrative presents the pro-choice debate held on men's bodily territory (male reproductive rights are being questioned instead of women's) and the latter depicts the literal commodification of spouses (husbands and not wives) who might be procured, returned or exchanged in market stores. "The Woman Who Guarded Gonads" destabilizes the so-called "pro-life" rhetoric by applying it to men's reproductive rights. The short story follows a man's application for a vasectomy, which in Ahern's dystopia, is illegal. The situation intentionally refers readers to the context of abortion in Ireland, which until recently, according to Article 40.3.3 of the Constitution, "the right to life of the unborn," was not legally permitted on demand (Connolly 71). The Eighth Amendment of 1983 put the equity sign between the foetus's right to live and that of the expectant woman. The male protagonist in "The Woman Who Guarded Gonads" does not want to have any more children and he appeals to the "right to choose what I do with my sperm" (Ahern 267). Since 1992, after the X Case of a raped 14-year-old girl who threatened to commit suicide, Irish women wishing to terminate pregnancy had to acknowledge being suicidal in order to justify their claim to abortion (Connolly 73). Correspondingly, the vasectomy-seeking protagonist in "The Woman Who Guarded Gonads" has to provide an account of his mental health and clarify whether he might take his own life. Similarly to Irish women who had to travel to the UK to abort a foetus, the man wishes to have a vasectomy abroad in a country where it is not forbidden by the law, but he is threatened with a restraining order. In "The Woman Who Guarded Gonads," the male character reiterates the pro-choice arguments: "You can't make a decision about my body, based on your personal opinions. IT'S MY SEMEN! THEY 
ARE MY TESTICLES!” (Ahern 268, emphasis in the original). However, his voice and his claims that "It's my body" and "It's got nothing to do with you!" (269) are not taken seriously by the female state officials just as the arguments of abortion-seeking women have hardly evoked any sympathy from Irish legislators and administrators. In "The Woman Who Guarded Gonads," the female bureaucrats mimic the anti-abortion rhetoric regarding the state's legitimization to control citizens' reproductive rights. Placards SAVE SEMEN and Guard the Gonads (emphasis in the original) manifest the governmental policies towards the need to control male fertility that female clerks support unquestioningly. Published just before the revoking of the Eighth Amendment in May 2018, "The Woman Who Guarded Gonads” expresses Ahern's support for Irish women's right to decide about their own fertility and their own bodies. Valuing the foetus over the life of the grown woman can lead to tragedy, as in the case of Savita Halappanavar who in 2012 in Ireland died of septic shock because her access to medically-induced termination of the life-threating pregnancy (diagnosed as impossible to carry) was repudiated by Galway Hospital. When admitted to the hospital, Halappanavar was having a painful miscarriage but doctors recommended waiting, which led to her critical condition, lethal infection and the woman's demise (O'Carroll).

In the dystopian reality of "The Woman Who Returned and Exchanged Her Husband," women can purchase husbands in Spousal Market shops. On submitting a receipt, wives have a life guarantee on their male partners, and they can change their minds any time, sending back undesirable companions to the retailer. The refund might be lower if the husband was previously on sale. The Spousal Market takes care of all return procedures. Conveniently, an unwanted husband is swiftly relocated in the company's vehicle to a new destination, and can be further re-sold on condition that his previous wife has given consent to it, and as long as he himself is open to it. Ironical as it may sound, the shop assistant asserts with conviction: "'We wouldn't put him back on the market without his permission, he's a human being-not a piece of meat" (Ahern 149). Unlike the nonexistent seller's market for older women, the "newly returned" mature men (149), who remained married for a long time, are much sought-after even in the alternate world. Comparable to an abandoned wife in the patriarchal reality, Paddy, the returned husband after forty years of marriage, pleads that he does not "want to be devalued" and wishes to be "appreciated for what ... [he is] truly worth"” (157). Ahern's short story "The Woman Who Returned and Exchanged Her Husband" mockingly subverts the malecontrolled convention in which youthful and sexually attractive female bodies are treated as men's prized properties, subject to a reimbursed replacement when women cease to meet their assigned, decorative criteria. 
Contemporary popular fiction criticism tends to stress the potential of the fantasy and the dream-like dimension in this literary convention (Killeen 56). Following this line of thinking, popular romantic fiction, rather than being simply regarded as reinforcing a male-controlled system of values, can also be interpreted as a reaction against the patriarchal order and a form of escape from its confining and unsatisfactory reality. In Reading the Romance: Women, Patriarchy and Popular Literature, Radway draws attention to the "wish-fulfilment fantasy" aspect of literature for women, which may constitute some compensation for the deficiencies and limitations of androcentric culture (151) but she also stresses its transformatory potential: " $[\mathrm{R}]$ omance reading might actually elicit and then deflect protest about the character of patriarchal social relations" (157).

Before exploring the beyond human corporeal female transformations in selected short stories from Roar, one needs to redefine the concept of the body in posthuman critique. In posthumanist thought, "the aesthetic, biological, medical, philosophical, religious paradigms ... produce and mediate the idea the idea of the normal, beautiful, sick or aged body" (Nayar 80). "The Women Who Ate Photographs" turns out to be an unexpectedly provocative narrative about the material assemblages of the body with the digested intake, which reveal themselves as recollections of past events. In this short story, the process of eating is depicted as

the formation of an assemblage of human and nonhuman elements, all of which bear some agentic capacity. This capacity includes the negative power to resist or obstruct human projects, but it also includes the more active power to affect and create effects. On this model of eating, human and nonhuman bodies reconceptualize in response to each other; both exercise formative power and both offer themselves as matter to be acted on. Eating appears as a series of mutual transformations in which the border between inside and outside becomes blurry. (Bennett 49)

Drawing upon Kass, Bennett claims that the eatable element becomes reconstructed and restructured into the eater (48). And this is the case in "The Women Who Ate Photographs" in which the protagonist's consumption of the family photos produces cerebral reminiscences. The digested paper actively induces psycho-somatic states, changing the temporality of woman's existence. Eating the photos transports the central character into the world of the affects connoted by that image: "she was chewing. ... a tidal wave of emotions, smells and memory enveloped her, wrapping her in a warm, cosy cocoon of love and nostalgia. She closed her eyes and swallowed" (Ahern 95-96). The process of retrieving the sensory data and transforming them into brain sensations and stimuli is rendered 
by means of all five basic faculties, i.e. the familiarity of her baby's fingers' touch, the aroma of his breath, the texture of "their old velvet couch beneath her legs" (96). The materiality of the photographic paper resists the process of ingestion: "Chewing photograph paper is difficult. It takes a lot to break down, her jaws ache, the taste makes her retch, but when she reaches the other side, the smells, the sounds, the sights flash into her mind, while the ache in her jaw and the bad taste fade away" (96). The narrative surprises readers with the tragic-comic relief of the seasoning of the photographs, adding olive oil and fusing them with other food. The protagonist experiments with "new ways to consume her memories; mixing the blended photos with tea-leaves, allowing them to infuse with boiling water" (98-99). In “The Women Who Ate Photographs," Ahern renders the discourse of the heroine's addiction in a specialized, drugrelated idiom, such as "the hit of nostalgia, the fix that transportation to another place gives her" (97). The writer precisely accounts for the cold turkey symptoms of withdrawal: "aches behind the eyes, stomach cramps, a trembling from inside as though caused by extreme hunger" (99). At the same time, as usual, the author "cannot resist the temptation to assist the reader in her interpretative efforts" (Radway 196), dispelling doubts that what the heroine craves is the sensation of being recognized by her family, "that warm cosy feeling of being wanted, needed, really yearned for makes her feel safer" (Ahern 99). With reference to narrative twists, Radway reminds one that the "romance perpetuates the illusion that, like water into wine, brusque indifference can be transformed into unwavering devotion" (151). In contrast to the fairy tale, the female character in "The Women Who Ate Photographs" is not awakened by a kiss like Sleeping Beauty but enters an active interaction. The materiality of the kiss (its taste, saliva, touch, etc.) that the protagonist exchanges with her husband expands the assemblage that she earlier created: "They communicate with each other through this kiss now. A new moment. It tastes better than any photograph” (Ahern 102).

Morphing posthuman female bodies develop not only re-formed but de-formed ("foreign") deviations from the so-called human anatomy. In doing so, they locate the protagonists of Ahern's narratives in the field of what MacCormack defines as posthuman teratology: "Arguably monstrosity is most often understood as a spectacle of flesh (in 'deformity') or of capability (in diffability for example). But it also includes patterns of nonspecular expressivity, such as behavioural or communicative diversions from what is considered within the spectrum of unremarkable behaviour" (7980). The de-formed female body can mutate and it metastasizes, producing "unnatural" growths, changing its cellular composition. In "The Woman Who Was a Featherbrain," the short story wittily incorporates scientific 
discourse; as an MRI scan shows that the heroine's brain has grown with feathers: "the left side-is mostly covered in this . . . feather . . . which affects your speech and language, mathematical calculation and fact retrieval, which explains your behaviour and the problems you've been experiencing" (Ahern 188). As in the proverbial scatterbrain condition, the protagonist's mind is diagnosed to have deteriorated, not being exercised enough and not being "as mentally challenged as... before" (190). The heroine graduated from Finance and Economics departments and did investment analyses in a top London-based company. Her current occupation "using my head in a different way" (190) is a euphemism for being a mother of four and a stay-at-home housewife. However, regardless of a firm declaration that " $[\mathrm{r}]$ aising people is vastly more important than stock markets or bullshit sales meetings," the central character's monologue betrays frustration ("this week my main project is potty training") and discomfort with her current situation ("my brain wants ... other information, other stimulation”); the heroine's speech reveals her resentment and reservations about the delights of full time childraising ("I haven't a clue what's going on in the stock markets but I can tell you every episode of every season of Peppa Pig") (190). The protagonist's $d$ windling intellect lacks the cerebral incentives and stimuli necessary for her personal self-development but she is also a monster-mother by the very fact of admitting that maternity does not satisfy all of her vital needs.

In "The Woman Who Found Bite Marks on Her Skin," the mechanism of auto-immune disease attacks the organism of the protagonist, manifesting itself via discernible corporeal self-aggression: bites on her skin. Her body, like an interactive platform, reverberates with androcentric pressures, " $[i] \mathrm{t}$ is the interface between nature's unique emergences of flesh and metaphysical attempts to make sense of that flesh" (MacCormack 79). For the protagonist of "The Woman Who Found Bite Marks on Her Skin," the "skin had become a patchwork quilt of guilt" (Ahern 55). The female character tormented herself about not being a good enough mother, neglecting her children when at work, and failing in her job due to being too absorbed in her family life, putting on weight or spending too much on her own needs, and so on. Jordan claims that in androcentric societies based on hierarchy and restraint one's vulnerability results from the lack of control over essential aspects of one's life (124). In "The Woman Who Found Bite Marks on Her Skin," each injury on the woman's body conspicuously signifies a failure to resist the self-blaming disease which has debilitated her entire existence. The narrator portrays the heroine's tormented mind and body in a gory Gothic manner. In the process, the abstract body turns into material posthuman flesh: "Her flesh had been devoured by hundreds of angry bite marks that began as nips but ended in blood-inducing tears of flesh. The physical pain was crippling" (Ahern 51-52). 
In "The Woman Who Unravelled," the apparent solidity of the heroine's corporeal framework disentangles to reveal the mesh of the threaded parts. "The Woman Who Unravelled" contains a surreal and uncanny conversational passage that effectively illustrates the process of defamiliarization: the scattered (bloody?) fibres of the female body create horrifying meshed entanglements with the seemingly familiar domestic interior. The following uncanny discussion demonstrates that neither son nor mother seem to be stunned by the fact of the parent losing an arm, and everything is swept under the carpet due to the lack of time in a busy morning domestic routine:

\section{"What's wrong, honey?" She asked. \\ "Mummy. You've got no arm."}

It was true. Her right arm was missing. She was holding her keys in her left hand and wondered how long it had been missing, how long she had been doing her morning chores without realizing she'd lost an arm. There was a thread of skin from her shoulder and a long line leading through the rooms of the house. Her son ran around picking it up as though playing a game. Skin bundled in his arms so high she could just see his brown eyes with giraffe-like lashes peeking out at her as she retrieved her arm from his arms. (Ahern 307-08)

As seen above, the filaments of the house (furniture, clothes) and that of the human body become intermingled: their contours are not clear as they form an assemblage of human and nonhuman. When each subsequent piece of the protagonist's body unknots and drops, the protagonist picks them up, hides and pretends not to notice this fact because she never has any time to attend to her own needs. The protagonist's body is deconstructed, "unravelled" and restructured again, as she calls it: "the unravelling of her was the making of her" (309). Within the posthuman approach, "body as a coherent, self-contained, autonomous self is no longer a viable proposition. We have to see the self as multiple, fragmented and made of the foreign" (Nayar 89). Wolfe captures it as follows: "[W] e can no longer talk of the body or even, for that matter, of $a$ body in the traditional sense. . . ' the body' is now seen as a kind of virtuality. . . . a virtual, multidimensional space produced and stabilized by the recursive enactions and structural couplings of autopoietic beings" (xxiii). The corporeal fragmentation in "The Woman Who Unravelled" is captured in a very literal way; the detached bodily pieces, the material tissue of her flesh, are stretched all over the house to be found on the floor or between the heroine's domestic utensils. Ahern's fiction contains some elements of considerably simplified, mass-market, posthumanist thought, but that does not mean it is posthuman in spirit per se: female characters wish to 
be "mended," and they see their other-than-human condition punitively as a disease to be cured. The pattern visible in Roar is that "post-humanity" brought to the surface allows them to identify the problem, and when the question is addressed and processed, the "abnormality" simply disappears. The philosophical dimension of the posthuman condition seems to be absent in Ahern's fiction. Wolfe rightly argues that

when we talk about posthumanism, we are not just talking about a thematics of the decentering of the human in relation to either revolutionary, ecological or technological coordinates (though that is where the conversation usually begins and, all too often ends); rather I will insist that we are talking about bow thinking confronts the thematics, what thought has to become in the face of those challenges. (xvi)

"The Woman Who Grew Wings" constitutes an exception in Roar: the protagonist's bodily alteration remains a desired and permanent element of her subjectivity. Growing wings is a bodily de-formation of practical usability, very much appreciated by the heroine. Her embodiment becomes "a multidimensional (interactive) space" organized around "structural couplings" (Wolfe xxiii) of several tropes which are activated simultaneously (anti-xenophobia being one of them). Ahern employs ethnic diversity in her narrative voices, and the protagonist of "The Woman Who Grew Wings" is a Muslim who wears the hijab, which ironically enables her to conceal the growing wings. To render the assemblage materiality of her re-constitution (human/animal/plant body cells), the female character compares the experience of extending bones and producing feathers to budding tree branches, concluding in a surprising way: "It isn't a weakening she feels in her body, it is a growing strength, spreading from her spine and arching across her shoulders" (Ahern 25). This empowering corporeal "abnormality" is misattributed by the medical profession to a hormonal imbalance in the woman's body. However, the real problems that the protagonist faces are not connected to health. The woman is a boat refugee and she feels alienated from the local community. She considers native inhabitants to be "polite and educated" (26) —but not empathetic-wealthy middle class citizens who live in secure, gated districts; "good people, these cappuccino-drinking, tennis-playing, coffeemorning fundraisers who care more about book weeks and bake sales than human decency" (26-27). The short story draws attention to racism, isolationism and the disciplining of immigrants in their resettlement places with "sidelong stares and uneasy silences" (26). The heroine in "The Woman Who Grew Wings" suspects that if local inhabitants could, they would do anything "to stop refugees and immigrants from entering their 
country" (26). Unlike other characters in the volume, the protagonist does not allow herself to be victimized and decides to make use of her transformed body and learn to fly. Furthermore, she boldly challenges the mothers from her children's school:

$[S]$ he looks the women directly in the eye, not afraid, not intimidated. She feels immense power, immense freedom, something these women don't understand-how could they? Their freedom has never been threatened, they have no experience of how effective war is in turning men, women and children to ghosts, in turning the mind into a prison cell, and liberty to a taunting fantasy. (30-31)

“The Woman Who Grew Wings" differs from other narratives included in Ahern's collection not only due to the audacious rather than passive attitude of the protagonist. In contrast to the previously discussed unwanted bodily alterations (feathers, unravelling, bite marks, etc.), wings are very much welcomed by the heroine. They epitomize the freedom that the protagonist has sought in her own war-ridden homeland and in her current xenophobic neighbourhood. The female character feels empowered to have them and she can appreciate the mobility they allow. Due to her wings, she can literally become a guardian angel for her children, capable of providing them with "[a] safe life. Everything they are entitled to. She closes her eyes, breathes in, feels her power. Taking her children with her, she lifts upwards to the sky and she soars" (32-33). However, the final resolution in the narrative does not put forward an actual solution to the problem: if the female character returns to the surface of the earth at some stage, the long-standing systemic obstacles will still be waiting for her there.

In conclusion, Ahern's collection Roar (2018) has some literary merits. I would like to underscore two of them here: the volume encompasses inclusive and diverse female voices and it incorporates elements of posthuman critique and postfeminist content into a mass audience dystopian framework, rendering it, at the same time, in a lighter, tongue-incheek manner. The collection has been praised for its "disarmingly downto-earth empathy" and modern fairy tale potential (Evans), and defined as "funny, wise and weighty-in a good way" (Patrick). While not being entirely ungrounded, critical reviews claiming that "Roar disappoints; the collection is largely saccharine and lacks subtlety and nuance," focus mostly on the "relevant and pressing subject" (Balter), missing entirely the nonrealistic, magical and romance dimension of Ahern's 2018 collection. I argue here that the structural shortcomings, such as repetitions or the avoidance of ambiguity, result from the conventions of the popular fiction genre in general and its female-oriented romance iteration in particular. In order to 
reach a wide reading public and sell millions of copies, popular literature needs to be tailored "for all," hence some necessary simplifications in the content and a preference for the unequivocal due to the requirements of the mass market. The combination of progressive ideas, aspects of postfeminist and posthumanist discourses and wide distribution necessitates serious compromises. It also cannot be denied that such a "marriage of convenience" does not always end with HEA: "they lived happily ever after." Ahern's Roar constitutes the best illustration of this thesis.

\section{Works CiTED}

Ahern, Cecelia. Roar. HarperCollins, 2018.

Balter, Ariel. "Roar: Thirty Stories, One Roar. A Book Review. New York Journal of Books, 16 Apr. 2019, https://www.nyjournalofbooks.com/ book-review/roar-thirty-stories-one-roar, accessed 15 Feb. 2021.

Bennett, Jane. Vibrant Matter: A Political Ecology of Things. Duke UP, 2010. "Cecelia Ahern." Cecelia Ahern, https://www.cecelia-ahern.com/about, accessed 15 Feb. 2021.

"Cecelia Ahern." Fantastic Fiction, http://www.fantasticfiction.com/a/ cecelia-ahern/, accessed 15 Feb. 2021.

Connolly, Linda, and Tina O’Toole. Documenting Irish Feminisms: The Second Wave. Woodfield, 2005.

Evans, Martina. “Roar Review: Cecelia Ahern's Fairy Tales Get Real.” The Irish Times, 3 Nov. 2018, https://www.irishtimes.com/culture/books/ roar-review-cecelia-ahern-s-fairy-tales-get-real-1.3673232, accessed 10 Nov. 2019.

Fiske, John. Understanding Popular Culture. Routledge, 1989. https://doi. org/10.4324/9780203837177

Gelder, Ken. Popular Fiction: The Logics and Practises of a Literary Field. Routledge, 2004. https://doi.org/10.4324/9780203023365

Genz, Stephanie, and Benjamin A. Brabon. Postfeminism: Cultural Contexts and Theories. Edinburgh UP, 2009.

Jordan, Judith V. "Restoring Empathic Possibility,” pp. 122-27. "Shame and Humiliation: From Isolation to Relational Transformation," by Linda M. Hartling, Wendy B. Rosen, Maureen Walker and Judith V. Jordan. The Complexity of Connection: Writings from the Stone Center's Jean Baker Miller Training Institute, edited by Judith V. Jordan, Maureen Walker and Linda M. Hartling, Guilford, 2004, pp. 103-28.

Killeen, Jarlath. "Nora Roberts: The Power of Love." Treenty-First-Century Popular Fiction, edited by Bernice M. Murphy and Stephen Matterson, Edinburgh UP, 2018, pp. 53-65. 
MacCormack, Patricia. Posthuman Ethics: Embodiment and Cultural Theory. Ashgate, 2012.

McRobbie, Angela. "Postfeminism and Popular Culture: Bridget Jones and the New Gender Regime." Interrogating Postfeminism: Gender and the Politics of Popular Culture, edited by Yvonne Tasker and Diane Negra, Duke UP, 2007, pp. 27-39. https://doi.org/10.1215/9780822390411002

Nayar, Pramod K. Posthumanism. Polity, 2014.

O’Carroll, Sinead. "Savita Halappanavar: Her Tragic Death and How She Became Part of Ireland's Abortion Debate." The Journal.ie, 29 Apr. 2018, https://www.thejournal.ie/eighth-amendment-4-3977441Apr2018/, accessed 15 Feb. 2021.

Patrick, Bethanne. "Roar by Cecelia Ahern, Book Review: 'Funny, Wise and Weighty_In a Good Way.”' Independent, 26 Apr. 2019, http:// www.independent.co.uk/arts-entertainment/books/reviews/ceceliaahern-roar-book-review-a8887711.htm; The Washington Post, 23 Apr. 2019, http://www.washingtonpost.com/entertainment/books/inroar-cecelia-ahern-uses-fables-to-delve-into-what-it-means-to-be-awoman/2019/04/22/b04a446c-61df-11e9-9412-daf3d2e67c6d_story. html; accessed 10 Nov. 2019.

Poloczek, Katarzyna. "From the Kitchen into the Bathroom: Feminist (post) Theory in Crisis." Theory That Matters: What Practice After Theory, edited by Małgorzata Myk and Kacper Bartczak, Cambridge Scholars, pp. 218-36.

Radway, Janice A. Reading the Romance: Women, Patriarchy and Popular Literature. The U of North Carolina P, 1991.

Tasker, Yvonne, and Diane Negra. "Introduction: Feminist Politics and Postfeminist Culture." Interrogating Postfeminism: Gender and the Politics of Popular Culture, edited by Yvonne Tasker and Diane Negra, Duke UP, 2007, pp. 1-25. https://doi.org/10.1215/9780822390411001

Wolfe, Cary. What is Posthumanism? U of Minnesota P, 2010.

Dr hab. Katarzyna Ostalska (née Poloczek) works in the Department of British Literature and Culture at the University of Lodz. She is the author of Towards Female Empowerment-The New Generation of Irish Women Poets: Vona Groarke, Sinéad Morrissey, Caitriona O'Reilly and Mary O'Donoghue (2015). She runs the Posthumanities Research Centre at the Faculty of Philology, the University of Lodz. https://orcid.org/0000-0001-8553-7517 katarzyna.ostalska@uni..lodz.pl 